\title{
An Angiographic Treatment for a Pancreatic Pseudoaneurysm
}

\author{
Mihai-Radu PAHOMEANU', Radu Bogdan MATEESCU², Bogdan DOROBAT ${ }^{1}$, Lucian NEGREANU'
}

\begin{abstract}
Interventional radiology has made significant progress to the care of severe acute pancreatitis complications with the introduction of percutaneous procedures. More recently, radiologic intervention has become the gold standard in treating a rare condition like pancreatic pseudoaneurysms. We report the case of an 40 years old male, heavy drinker and smoker, at the second episode of acute pancreatitis that developed an pseudoaneurysm cured through angiographic embolotherapy.
\end{abstract}

Keywords: pseudoaneurysm, acute pancreatitis, angiography, embolotherapy.

\section{Rezumat}

Radiologia intervențională a făcut progrese majore în îngrijirea complicaților severe ale pancreatitei acute odată cu introducerea procedurilor percutane. Mai recent, intervențiile radiologice au devenit standardul de referință în tratarea patologiilor rare precum pseudoanevrismele pancreatice. Vă prezentăm cazul unui bărbat de 40 de ani cu etilism cronic și fumător care la cel de al doilea episod de pancreatită acută a dezvoltat un pseudoanevrism pancreatic pe artera pancreatico-duodenală inferioară tratat prin angioembolizare.

Cuvinte cheie: pseudoanevrism, pancreatită acută, angiografie, angioembolizare.

\section{INTRODUCTION}

Pancreatic pseudoaneurysm is a visceral arterial pseudoaneurysm, with an estimated prevalence by several case series at around 1.3 to $10 \%$ of total acute pancreatitis complications ${ }^{2}$. The pancreatic pseudoaneurysm is caused by the communication between a pancreatic or peripancreatic artery with a pseudocyst that trough proteolytic enzymes is eroding into an artery. Compared with a true aneurysm, the wall of pseudoaneurysm are made from a fibrous tissue, and not by the arterial wall, being more prone to rupture ${ }^{3}$.

The most prevalent location for pancreatic pseudoaneurysm is the splenic artery (50\%) followed by gastroduodenal artery (20\%), pancreaticoduodenal artery (10\%) with the remainder on proper hepatic and superior mesenteric arteries ${ }^{2}$. The classification of pancreatic pseudoaneurysms proposed by Pang et. al. ${ }^{4}$ refers to three elements: the type of artery involved, the

\footnotetext{
1 Department of Gastroenterology-Internal Medicine, Emergency University Hospital, "Carol Davila" University of Medicine and Pharmacy, Bucharest, Romania

2 Department of Gastroenterology, Colentina Hospital, „Carol Davila" University of Medicine and Pharmacy, Bucharest, Romania
}

Corresponding author. Mihai-Radu PAHOMEANU, Department of GastroenterologyInternal Medicine, Emergency University Hospital, Bucharest, ROmania. E-mail: paho93@gmail.com 
communication with the GI tract and the exposure to pancreatic juice at the bleeding site.

The main aetiology of pseudoaneurysm is acute pancreatitis but it can be also seen after biliopancreatic resection for cancer, local abscess or after pancreatic transplantation ${ }^{1}$.

The prognosis in this pathology depends a lot on the type of therapy applied. Treatment with supportive measures have an estimated mortality in excess of $90 \%$, after surgical treatment is around 28 to $56 \%$ and after embolization therapy $16 \%{ }^{1}$.

Physical examination is not specific, most of the patients being asymptomatic. In case of rupture the patient can present: abdominal pain, recurrent and intermittent, digestive haemorrhage, anemia of unexplained etiology and rapid enlargement of an otherwise stable pseudocyst ${ }^{5}$.

Angiography is the gold standard in determining diagnosis being also a mean of treatment. Also, CTA (CT angiography) or MRA (MR angiography) can be used in identifying the site of the lesion1.

\section{CASE REPORT}

A 40 years old male, heavy drinker and smoker, with multiple episodes of recurrent acute pancreatitis on a chronic pancreatitis was admitted to Colentina Hospital with upper abdominal pain, nausea and malaise.

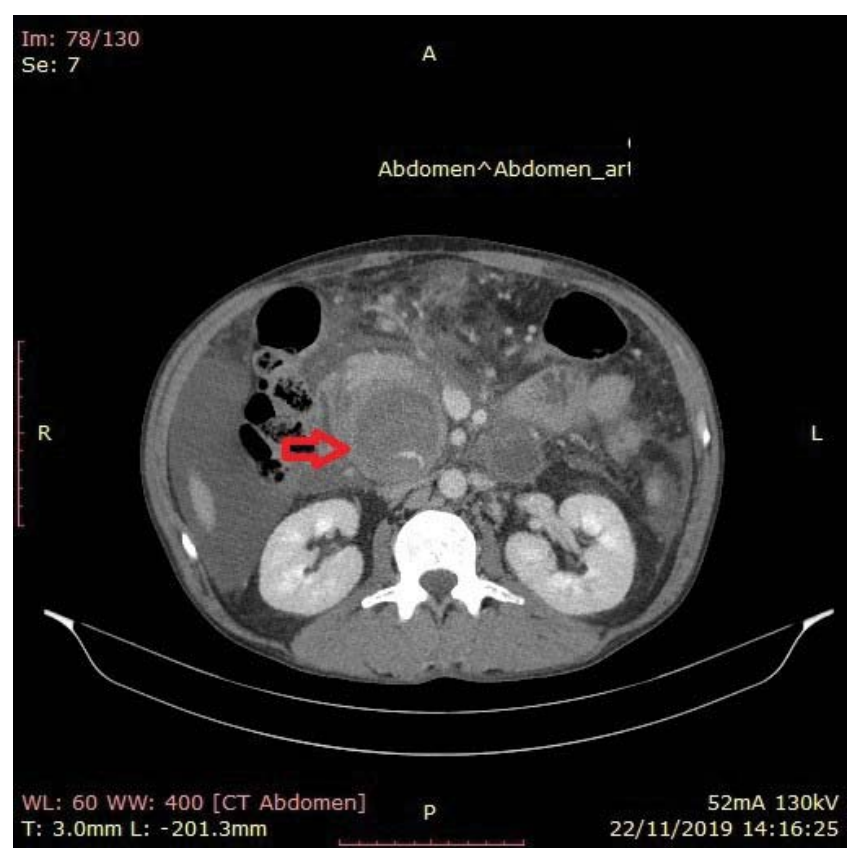

Figure 1. CT scan performed at Colentina Hospital showing the pseudoaneurysm (red arrow).
The laboratory exam made at admission found elevated serum lipase and amylase. During his hospitalisation he presented an acute episode of arterial hypotension, acute anemia and haemodynamic instability for which it was performed an CT exam with arterial contrast. The CT scan identified an intra-cystic-haemorrhage, measuring $5.1 \mathrm{~cm}$ on its largest diameter, located on the pancreaticoduodenal inferior artery. It was then decided to be transferred to University Emergency Hospital of Bucharest for evaluation.

On admission at University Emergency Hospital, the patient was cachexic, had pale skin, suffered diffuse abdominal pain, had arterial hypotension $(\mathrm{BP}=90 / 50 \mathrm{mmHg})$ and sinus tahycardia ( $\mathrm{HR}=$ $120 \mathrm{bpm})$. The laboratory exam revealed: reduction in red blood cells $(\mathrm{HCT}=26.5 \%)$, high platelet count $(\mathrm{PLT}=468.000 / \mathrm{mL})$, hypocromic anemia $(\mathrm{HGB}=8.5$ $\mathrm{g} / \mathrm{dL}, \mathrm{MCHC}=32.2 \mathrm{~g} / \mathrm{dL}$ ), hyposideremia (Serum Iron=27 mg/dL), elevated serum lipase $1.5 \mathrm{XN}(148$ $\mathrm{U} / \mathrm{L})$ and amylase $1.5 \mathrm{XN}(200 \mathrm{U} / \mathrm{L})$ and low fibrogenemia $(\mathrm{FBG}=159.56 \mathrm{mg} / \mathrm{dL})$.

The angiographic exam revealed a pseudoaneurysm on the inferior pancreaticoduodenal artery, classified as type IIA2. It was then performed a embolization with a coil type VortX (Boston Scientific, USA) with no periprocedural complications that resulted in complete exclusion of the pseudoaneurysm from the circulation.

Patient was discharged $48 \mathrm{~h}$ post procedure.

\section{DISCUSSION}

Pancreatic pseudoaneurysm (PPA) carries a poor outcome. PPA is in fact a complication of acute pancreatitis, that compared to true aneurysms has a high rate of rupture $(76.3 \% \text { versus } 3.1 \%)^{11}$ and so it should be treated immediately.

Several studies ${ }^{4,12}$ have identified a overall mortality rate in ruptured PPA ranging from 0 to $60 \%$, the mortality rate being larger when the etiology is post-surgical than the one post-acute pancreatitis ( $31 \%$ vs. $4 \%$ ). It is very hard to define long-term strategies in this disease, due to the scarcity of the cases, but on short-term management most of the cases published after 2000 were treated through endovascular embolization (46$92 \%)^{12,13}$. Two studies have suggested that hemodynamically unstable patients can be managed successfully with endovascular interventions ${ }^{15,16}$.

Treatment options available today are: surgical, endovascular or percutaneous ${ }^{5}$. The endovascular treatment seems to be the first choice nowadays, with success rates 


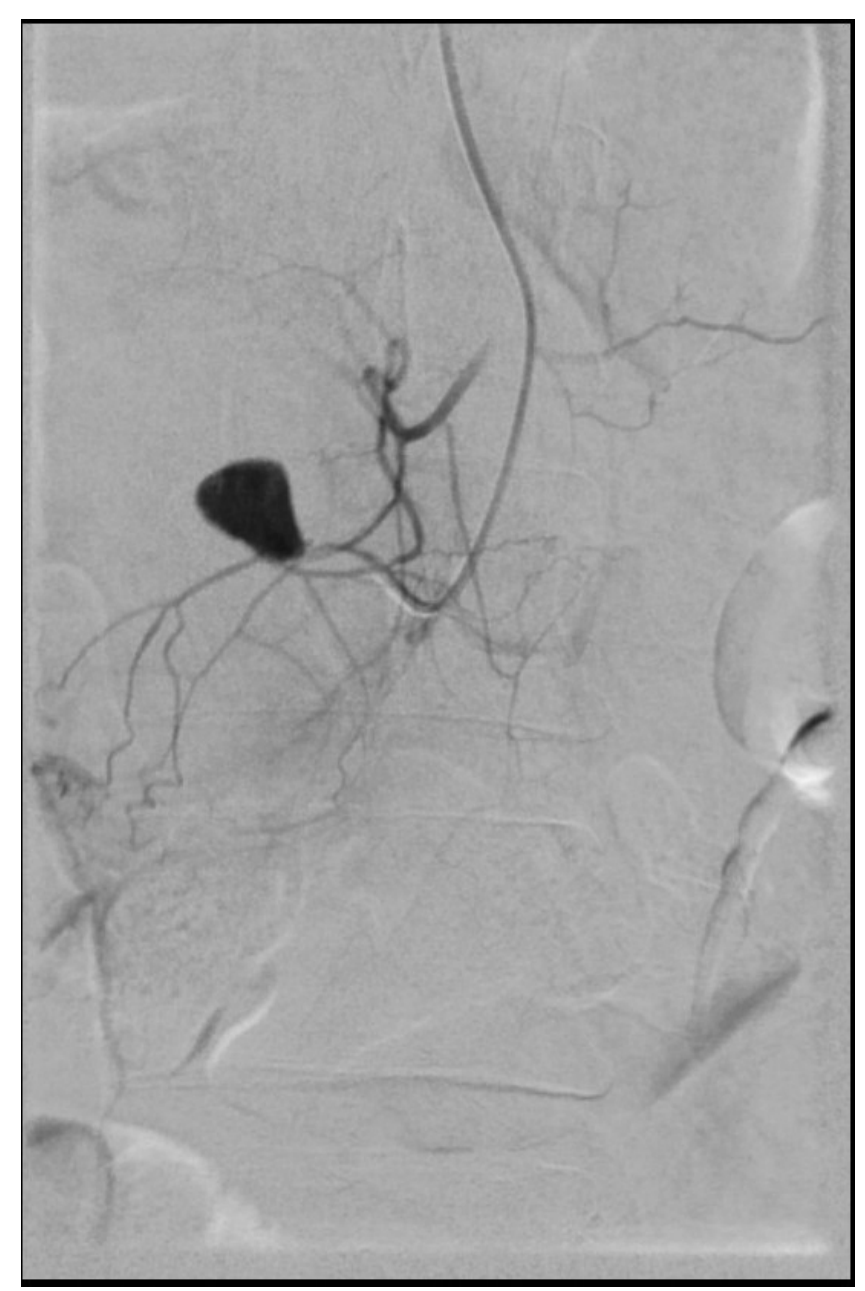

Figure 2. Pancreatic pseudoaneurysm before the embolization.

ranging from $77 \%$ to $100 \%, 30$ day aneurysm-related mortality $3.4 \%$ and periprocedural-related mortality $6.2 \%{ }^{7-10}$. Several materials can be used in endovascular embolization, the most common ones being: coils, gelatin foam, polyvinyl alcohol, trisacryl gelatin microspheres, amplatzer vascular plugs, cyanoacrylate glue, ethylene vinyl alcohol copolymer and calcium alginate $\mathrm{ge}^{14}$. In case of an unsuited anatomy for endovascular procedure or failure of endovascular procedure the first line of treatment should be the surgical one.

The prognosis of embolization therapy on pancreatic pseudoaneurysm, cited by the literature, indicates a successful technique in 77 to $100 \%$ of cases, rates resulted from several small retrospective studies made in the first half of second decade of $21^{\text {th }}$ century ${ }^{6-10}$, recurrence rate of $37 \%$ and an overall mortality of $16 \%{ }^{1}$.

Post procedure complications can arise in endovascular therapy, most commonly described being: local complications at the access site (thrombosis, embolism, hematoma, pain, cellulitis, infection or local pseudoaneurysms), contrast agent nephropathy, visceral ischemia, coil migration, post-embolization syndrome or intraprocedural pseudoaneurysm rupture.

\section{CONCLUSIONS}

The golden standard in PPA treatment is endovascular selective embolization. We successfully applied this approach in a young patient with a ruptured PPA.

Compliance with ethics requirements: The authors declare no conflict of interest regarding this article. The authors declare that all the procedures and experiments of this study respect the ethical standards in the Helsinki Declaration of 1975, as revised in 2008(5), as well as the national law. Informed consent was obtained from all the patients included in the study.
Figure 3. Angiography after selective embolization of the pancreatic pseudoaneurysm, showing here the complete exclusion from the vascular structures.

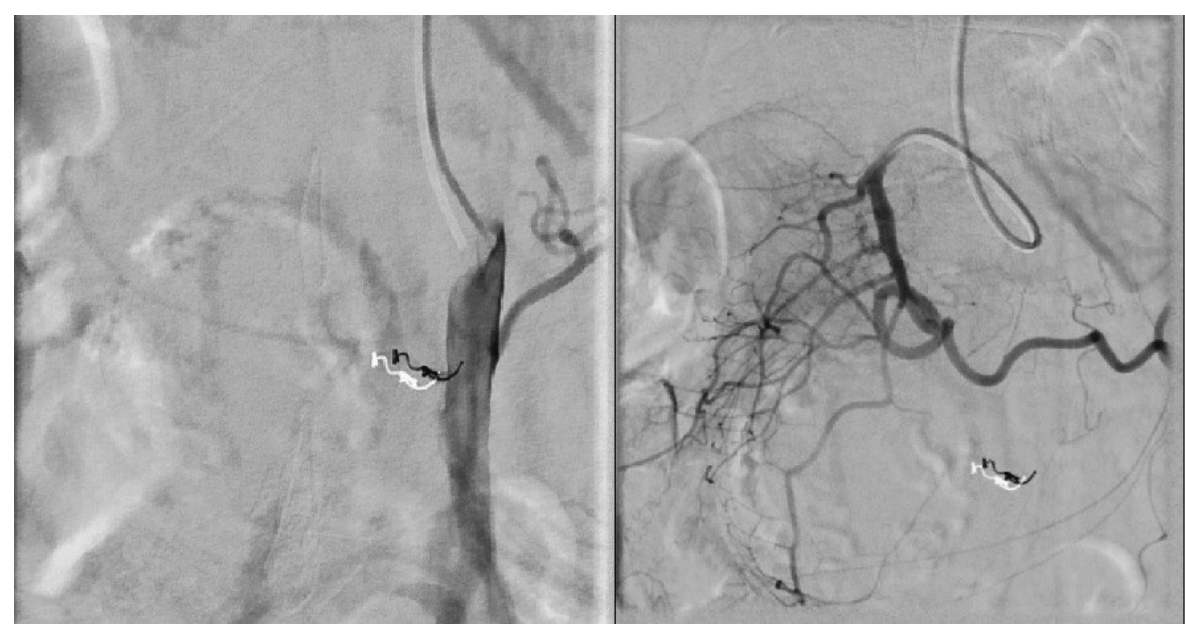




\section{References}

1. Aziz, Faisal and Savino, John. Pancreatic Pseudoaneurysm Medscape. [Online] February 07, 2020. [Cited: February 22, 2020.] https://emedicine.medscape.com/article/191880-overview.

2. Verde, Franco, Fishman, Elliot K. and Johnson, Pamela T. Arterial Pseudoaneurysms Complicating Pancreatitis. Journal of Computer Assisted Tomography. January/February, 2015, Vol. $39,1$.

3. Sumpio, Bauer, et al. Overview of visceral artery aneurysm and pseudoaneurysm. UpToDate. [Online] March 11, 2019. [Cited: February 22, 2020.] https://www.uptodate.com/contents/overview-of-visceral-artery-aneurysm-and-pseudoaneurysm.

4. Pang, Tony C. Y., et al. Peripancreatic pseudoaneurysms: a management-based classification system. Surgical Endoscopy. July 2014, 2014.

5. Abdelgabar, A, et al. Visceral artery pseudoaneurysms: two case reports and a review of the literature. Journal of Medical Case Reports. [Online] May 4, 2017. [Cited: February 23, 2020.] https:// jmedicalcasereports.biomedcentral.com/articles/10.1186/ s13256-017-1291-6.

6. Spiliopoulos, S., Sabharwal, T. and Karnabatidis, D. Endovascular treatment of visceral aneurysms and pseudoaneurysms: long-term outcomes from a multicenter European study. Cardiovasc Intervent Radiol. 2012, Vol. 35, 6.

7. Fankhauser, GT, et al. The minimally invasive management of visceral artery aneurysms and pseudoaneurysms. J Vasc Surg. 53, 2011.
8. Sethi, $\mathrm{H}$, et al. Selective embolization for bleeding visceral artery pseudoaneurysms in patients with pancreatitis. Hepatobiliary Pancreat Dis Int. 9, 2010.

9. Balderi, A, et al. Endovascular treatment of visceral artery aneurysms and pseudoaneurysms: our experience. Radiol Med. $117,2012$.

10. Won, $Y$, et al. Clinical efficacy of transcatheter embolization of visceral artery pseudoaneurysms using $\mathrm{N}$-butyl cyanoacrylate (NBCA). Diagn Interv Imaging. 96, 2015.

11. Pitton, $M B$, et al. Visceral artery aneurysms: incidence, management, and outcome analysis in a tertiary care center over one decade. Eur Radiol. 2015, Vol. 25

12. Zyromski, NJ, et al. Improved outcomes in postoperative and pancreatitis-related visceral pseudoaneurysms. J Gastrointest Surg. January, 2007, Vol. 11, 1.

13. Bergert, $\mathrm{H}$, et al. Management and outcome of hemorrhage due to arterial pseudoaneurysms in pancreatitis. Surgery. March, 2005, Vol. 137, 3

14. Vaidya, S, Tozer, KR and Chen, J. An overview of embolic agents Semin Intervent Radiol. September, 2008, Vol. 25, 3.

15. Sachdev, $U$, et al. Management of aneurysms involving branches of the celiac and superior mesenteric arteries: a comparison of surgical and endovascular therapy. J Vasc Surg. 2006, Vol. 44.

16. Dohan, $A$, et al. Role and effectiveness of percutaneous arterial embolization in hemodynamically unstable patients with ruptured splanchnic artery pseudoaneurysms. Cardiovasc Intervent Radiol. 2015, Vol. 38 